ISSN : 2615-1995, E-ISSN : 2615-0654

J. Madani., Vol. 4, No. 1, Maret 2021 (24 - 33)

(C)2018 Lembaga Kajian Demokrasi

\title{
Value Added Intellectual Capital Memoderasi Pengaruh, Leverage, Risiko Sitematis, Growth Opportunities, dan Firm Size Terhadap Earning Response Coefficient (ERC)
}

\author{
Ari Gunawan \\ Program Pasca Sarjana Magister Akuntansi, Universitas Pancasila \\ arigunawan14041@gmail.com \\ Choirul Anwar \\ Program Pasca Sarjana Magister Akuntansi, Universitas Pancasila \\ anwar_choirul@yahoo.com \\ Syahril Djaddang \\ Program Pasca Sarjana Magister Akuntansi, Universitas Pancasila \\ syahril@univpancalisa.ac.id
}

\begin{abstract}
Abstrak
Studi ini bertujuan untuk melakukan pengujian value added intellectual capital memoderasi pengaruh, leverage, risiko sistematis, growthopportunities dan firm size terhadap earning responsecoefficient (ERC). Penelitian ini dilakukan pada perusahaaan otomotif yang terdaftar di BEI pada periode 2013-2017 dengan teknik purposive sampling diperoleh jumlah sampel sebanyak 58 perusahaan. Teknik analisis data yang digunakan dalam penelitian ini adalah teknik Struktur Equation Modeling WarpPLS 6.0. . Dari hasil pengujian hipotesis dengan mengunakan teknik Struktur Equation Modeling SEM-PLS, dapat disimpulkan bahwa : Leverage tidak berpengaruh terhadap ERC, hasil penelitian ini searah dengan prespektif manajerial (Teori Trade Off). Resiko sistematis berpengaruh negatif terhadap ERC, hasil penelitian ini ini searah dengan motif risiko. Growth Opportunities berpengaruh positif terhadap ERC, Hasil penelitian ini searah dengan teori akuntnasi positif.Firm Sizetidak berpengarug terhadap ERCartinya perusahaan tidak mampu memanfaatkan aset yang dimiliki untuk menciptakan profitabilitas perusahaan. VAIC tidak memoderasi hubungan antara Leverage, Resiko sistematis, Growth Opportunities, Firm Size terhadap ERC. Value Added Intelectual capital memiliki subyektifitas yang tinggi karena pengukuran VAIC belum dapat dilakukan dengan tepat terhadap IC perusahaan, karena belum ada alat ukur yang tepat untuk menghitung IC perusahaan.
\end{abstract}

Kata Kunci : Earning Response Coefficient, Leverage, Resiko sistematis, Growth Opportunities, Firm Size, VAIC 


\begin{abstract}
Objective of this research is to test value added intellectual capital to moderate influence, leverage, systematic risk, growth opportunities and firm size against earnings response coefficient (ERC). This research was conducted on listed automotive companies on the BEI in the period 2013-2017 with purposive sampling technique. The number of samples we obtained is 58 companies. Data analysis technique that we used in this research is Structure Equation Modeling technique WarpPLS 6.0. Results of hypothesis testing by using Structure Equation Modeling technique SEM-PLS, is that: Leverage does not affect the ERC, the results of this study is in line with managerial perspective (Trade Off Theory). Systematic risk have negative affect with the ERC, the results of this study is in line with the risk motive. Growth Opportunities positively affect the ERC, The results of this study is in line with positive accounting theory. Firm Size does not affect the ERC, it means the company is not able to take advantage of owned assets to create company profitability. VAIC does not moderate the relationship between Leverage, Systematic Risk, Growth Opportunities, Firm Size against ERC. Value Added Intelectual capital has a high subjectivity because VAIC measurements can not be done properly against corporate IC, because there is no appropriate measuring tool to calculate the company IC.
\end{abstract}

Keywords : Earning Response Coefficient, Leverage,Resiko sistematis, Growth Opportunities,

Firm Size, VAIC

\section{PENDAHULUAN}

Pernyataan Standar Akuntansi Keuangan (PSAK) No. 1 menyatakan laba memiliki manfaat untuk menilai kinerja manajemen, membantu mengistimasi kemampuan laba yang representative dalamjangkapanjang, memprediksi laba dan menaksir resiko dalam investasi atau kredit (FASB,1985). Laporan keuangan dan laporan tahunan merupakan salah satu informasi yang secara formal wajib dipublikasikan. Informasi yang dipublikasikan tersebut harus dapat mengungkapkan kondisi keuangan yang sebenarnya, sehingga bermanfaat bagi masyarakat umum. Informasi yang bermanfaat bagi masyarakat umum adalah informasi yang dapat digunakan untuk pengambilan keputusan yaitu informasi yang relevan. Salah satu indikator bahwa suatu informasi akuntansi relevan adalah adanya reaksi pemodal pada saat diumumkannya suatu informasi yang dapat diamati dari pergerakan harga saham, informasi yang dapat digunakan untuk pengambilan keputusan tersebut adalah laba akuntansi (Naimh, 2014).

Laporan keuangan merupakan sumber informasi keuangan yang diberikan oleh perusahaan kepada publik, terutama kepada investor dan kreditur, informasi laba merupakan salah satu bagian dari laporan keuangan yang banyak mendapat perhatian. Lev dan Zarowin (1999) dalam Novi Liya Sari (2016) menggunakan Earnings Response Coefficient (ERC) sebagai alternatif untuk mengukur value relevance informasi laba Rendahnya ERC menunjukan bahwa laba kurang informatif bagi investor untuk membuat suatu keputusan ekonomi. Sehubungan dengan pentingnya informasi mengenai laba bagi perusahaan publik terutama untuk investor dan kreditur, Bapepam memberikan Pedoman Penyajian dan pengungkapan Laporan Keuangan Emiten atau Perusahaan Publik (P3LKEPP).

Dari beberapa hasil penelitian tersebut seperti yang telah dilakukan oleh Jati, N. A., Khairunnisa, K., \& Yudowati, S. P. (2017). Hasil penelitian menunjukkan bahwa: (1) risiko sistematik, persistensi laba, dan ukuran perusahaan berpengaruh signifikan terhadap koefisien respon laba, (2) risiko sistematik berpengaruh signifikan negatif terhadap koefisien respon laba, (3) persistensi laba tidak berpengaruh terhadap koefisien respon laba, dan (4) ukuran perusahaan berpengaruh signifikan negatif terhadap koefisien respon laba. Kata kunci: Risiko Sistematik, Persistensi Laba, Ukuran Perusahaan, Koefisien Respon Laba. Berbeda dengan hasil penelitian Sulistyorini, Y. (2016), menunjukan bahwa kondisi DER mengalami tren meningkat secara elastis, kondisi Sales Growth mengalami tren menurun secara sangat elastis, kondisi ROA mengalami fluktuasi yang relative cukup tajam dengan tren menurun secara elastis, sedangkan kondisi Firm Size mengalami tren meningkat secara elastis. 
Selain menggunakan Earnings Response Coefficient (ERC) sebagaialternatifuntuk mengukur value relevance informasi laba Rendahnya $E R C$, Value Added Intellectual Coefficient di gunakan juga sebagai penambahan alat ukur penelitian ini.

Menurut Ghosh, SK, \& Maji, SG (2015), Hasil penelitian menunjukkan bahwa VAIC berpengaruh positifdan signifikan terhadap kinerja perusahaan yang diukur dengan rasio return on asset (ROA) dan market-to-book (M / B). Seluruh komponen VAIC kecuali structural capital (SC) efficiency (SCE) berpengaruh signifikan dan positif terhadap kinerja perusahaan. Hubungan yang tidak signifikan antara SCE dan kinerja perusahaan, Seperti yang diamati dalam konteks sekarang dan juga diamati sebelumnya oleh banyak peneliti, mungkin dianggap sebagai ketidaksesuaian model dalam menangkap modal struktural. Untuk memodifikasi komponen SC model, komponen model VAIC diperpanjang dapat digunakan sebagai entitas yang menciptakan nilai. Menurut hasil penelitian yang di lakukan oleh Ulum, I., Kharismawati, N., \& Syam, D. (2017), memperluas pemahaman tentang peran modal intelektual dalam menciptakan nilai perusahaan dan membangun keuntungan berkelanjutan bagi perusahaan di negara berkembang.

Hasil penelitian sebelumnya dilakukan oleh Agustiningrum, S. A. (2020) dengan Teknik pengambilan sampel menggunakan purposive judgement sampling sebanyak 120 perusahaan sebagai sampel yang sudah masuk kriteria. Instrumen uji statistik dalam penelitian ini yaitu versi WarpPLS 5.0. Hasil penelitian ini menunjukkan bahwa modal intelektual, leverage dan profitabilitas tidak berpengaruh terhadap koefisien respon laba. Pengungkapan tanggung jawab sosial perusahaan tidak dapat memoderasi modal intelektual, leverage, dan profitabilitas terhadap koefisien respons laba.

Di Indonesia, fenomena Intelectual Capital (IC) mulai berkembang terutama setelah munculnya PSAK No. 19 (revisi 2009) tentang aktiva tidak berwujud. Dan pada umumnya alat ukur untuk mengetahui factor kenaikan laba pada perusahaan dilihat dari Leverage, Resiko sistematik (beta), Growth Opportunities, Firm Size dan Earnings response coefficient (ERC).

Setelah adanya penelitian yang dilakukan oleh peneliti sebelumnya terkait Intelectual Capital (IC) dan adanya hasil penelitian terhadap factor penyebab kenaikan laba, Penyusun tertarik untuk mengetahui keterkaian Intelektual Capital sebagai pemoderasi terhadap pengaruh tren kenaikan laba atau Earning Response Coefficient (ERC). Maka peneliti ini dilakukan terhadap perusahaan otomotif dan komponen yang terdaftar di BEI.

\section{METODE}

Penelitian ini merupakan jenis penelitian kuantitatif dan dilakukan terhadap perusahaan go public di sector otomotif dan komponen Bursa Efek Indonesia (BEI), dengan mengamati dan menganalisa obyek penelitian yang terdiri atas variable-variabel yang diteliti yaitu variable Leverage, Resiko sistematik (beta), Growth Opportunities, Firm Size dan Earnings response coefficient (ERC). Adapun dimensi penelitian ini mencakup waktu lima tahun yakni tahun 20132017. Penelitian ini dilakukan di Bursa Efek Indonesia (BEI) dengan mendatangi langsung ke BEI di Jakarta, dan juga mengunjungi website BEI.

\section{Pengukuran Variabel}

\section{Variabel Dependen}

Variabel dependen dalam penelitian ini adalah Earnings Response Coefficient. Besarnya ERC diperoleh dengan melakukan beberapa tahap perhitungan.

Cumulative abnormal return(CAR)

Cumulative abnormal return (CAR) merupakan proksi dari harga saham atau reaksi pasar.

$$
\mathrm{Ab}(\mathrm{R}) \mathrm{R} i t-\mathrm{R} i
$$

Keterangan:

$\mathrm{Ab}(\mathrm{R})$ : Abnormal return sekuritas ke- $i$ pada perioda peristiwa ke $t$

Rit : Return saham ke-i pada perioda peristiwake $t$

Ri : Return ekspektasi sekuritas ke-i pada perioda peristiwa ke $t$

a. Pendapatan saham yang sebenarnya (actual return)

Actual return merupakan pendapatan yang telah diterima investor berupa capital gain yang didapatkan dari perhitungan:

$$
\text { Rit }=\frac{p_{t}-p_{t}-1}{p_{t}-1}
$$

Keterangan:
Rit $=$ Actual return saham perusahaan $i$ perioda peristiwa $t$
$\mathrm{P} t=$ Harga saham pada perioda peristiwa ke $t$
$\mathrm{P} t-1=$ Harga saham pada perioda peristiwa $t-1$ 


\section{b. Return Ekspektasi}

Model yang digunakan untuk estimasi abnormal return adalah Mean-adjusted return (Brown dan Warner, 1985) yang didefinisikan.

Dimana:

$$
R i=\frac{\sum_{j=t 1}^{T 2} E\left(R_{i t}\right)}{T}
$$

$\mathrm{R} i=$ Return ekspektasi sekuritas ke- $i$ pada periode peristiwa ke- $t$

$\mathrm{E}(\mathrm{R} i t)=$ Return realisasi sekuritas ke- $i$ pada periode estimasi ke- $t$

$\mathrm{T}$ = Lamanya periode estimasi, yaitu dari $t 1$ sampai dengan $t 2$

$\mathrm{P} t-1=$ Harga saham pada perioda peristiwa $t-1$

\section{c. Unexpected Earnings (UE)}

Unexpected earnings diukur menggunakan pengukuran Suaryana (2004):

$$
U E_{i t}=\frac{\left(E_{i t}-E_{i t}-1\right)}{E_{i t}-1}
$$

Keterangan:

$\mathrm{UE} i t=$ Unexpected earnings perusahaan $i$ pada perioda (tahun) $t$

Eit $=$ Laba akuntansi perusahaan $i$ pada perioda (tahun) $t$

Eit-1 = Laba akuntansi perusahaan $i$ pada perioda (tahun) sebelumnya $(t-1)$

Akumulasi return abnormal dalam jendela pengamatan di definisikan sebagai berikut:

$$
C A R_{i, t}[t 1-t 2]=\sum A R_{i, t t=t 1}
$$

Keterangan:

AR $i, t=$ abnormal return kumulatif perusahaan $i$ selama perioda tahun

$(t) t 1-t 2=$ panjang interval pengamatan return saham atau perioda akumulasi dari $t 1$ hingga (termasuk) $t 2$.

Setelah mengetahui hasil dari Rumus Earning Response Coefficient (ERC)

$E R C$ dinyatakan secara matematik

$$
\mathrm{R}=\mathrm{a}+\mathrm{b}(\mathrm{ern}-\mathrm{u})+\mathrm{e}
$$

Dimana

$\mathrm{R} \quad=$ Tingkat pengembalian yang diharapakan

a = Suku bunga atau acuan

$\mathrm{b}=$ Kooefisien respon laba ern-u $=$ Nilai pendapatan tak terduga

$\mathrm{e} \quad=$ Gerakan acak

\section{Variabel Independen}

Variabel independen (variabel bebas) adalah variabel yang mempengaruhi variabel tidak bebas. Sehubungan dengan hipotesis di atas maka variabel independen dalam penelitian ini adalah leverage, Resiko sistematik (beta), Growth Opportunities (market to book value ratio), dan Firm size. Definisi operasional dalam penelitian ini adalah sebagai berikut :

\section{1) Leverage}

Variabel ini menunjukkan bahwa $E R C$ akan rendah jika perusahaan mempunyai leverage yang tinggi. Dhaliwal et al. (1991). Leverage dirumuskan sebagai berikut:

$$
L e v_{i t}=\frac{T U_{i t}}{T A_{i t}}
$$

\section{Keterangan :}

$\mathrm{TU}=$ Total utang perusahaan $i$ pada tahun $t$

$\mathrm{TA}=$ Total aset perusahaan $i$ pada tahun $t$.

\section{2) Risiko sistematik (Beta)}

Risiko diukur menggunakan risiko sistematik (beta) dengan menggunakan market model (Hartono, 2003) dengan mengunakan rumus $C A P M$ sebagai berikut:

$$
\mathrm{Rit}=\alpha \mathrm{i}+\beta \mathrm{it} \mathrm{R} m t+\varepsilon i t
$$

Keterangan:

Rit: Return perusahaan $i$ tahun $t$

Rmt: Return pasar pada tahun $t$

\section{3) Growth Opportunities (Market to book value ratio)}

Variabel ini diukur dari market to book value ratio masing-masing perusahaan pada perioda akhir perioda laporan keuangan, (Jaswadi, 2003), yang dirumuskan sebagai berikut:

Market To Book Ratio

\section{Nilai Pasar Ekuitas}

Nilai Buku Ekuitas

\section{4) Ukuran Perusahaan (Firm Size)}

Variabel yang diukur dengan total aktiva (Collins dan Kothari, 1989). 


\section{Metode Analisa Data}

Untuk penelitian ini menggunakan alat analisis Struktur Equation Modeling SEM-PLS dengan Program WarpPLS 6.0. adalah Variance atau component based Struktur Equation Modeling (WarpPLS) digunakan untuk menguji hipotesis. Alat analisis ini dipilih karena ada beberapa kelebihan yaitu didesain untuk dapat menyelesaikan persoalan seperti jumlah sampel yang kecil, data tidak terdistribusi normal secara multivariate, adanya missing value, dan adanya problem multikolonieritas antar variabel eksogen (Latan dan Ghozali 2012).

Menurut Ghozali dan Latan (2014) menyatakan bahwa tahapan model analisis menggunakan SEM-PLS dengan WarpPLS 6.0 setidaknya harus melewati lima proses tahapan yaitu sebagai berikut:

\section{Konseptualisasi Model}

Tahap ini peneliti harus mendefinisikan secara konseptual konstruk yang diteliti dan menentukan dimensionalitasnya. Arah hubungan kausalitas antar konstruk yang dihipotesiskan ditentukan dengan indikator pembentuk konstruk laten harus ditentukan apakah berbentuk reflective ataukah formative. Indikator penelitian ini pembentuk konstruk laten berbentuk formative. Konstruk dengan indikator formative mengasumsikan bahwa setiap indikatornya mendefinisikan atau menjelaskan karakteristik domain konstruknya.

\section{Menentukan Metode Analisis Algorithm}

Metode analisis analisis algorithm yang digunakan untuk estimasi model. Dalam WarpPLS 6.0 ada empat pilihan metode analisisalgorithm yaitu WarpPLS Regression, WarpPLS Regression, PLS Regression dan Robust Path Analysis. Setelah menentukan metode analisis algorithm yang digunakan, kemudian menentukan berapa jumlah sampel yang harus dipenuhi. Penelitian ini analisis algorithm yang digunakan adalah $P L S$ Regression dengan number of data resamples yang digunakan sebesar 58 .

\section{Menentukan Metode Resampling}

Untuk melakukan resampling kembali menggunakan metode bootstrapping dan jackknifing. Metode bootstrapping menggunakan seluruh sampel asli untuk melakukan resampling kembali. Sedangkan metode jackknifing hanya menggunakan subsampel dari sampel asli yang dikelompokkan ke dalam grup untuk melakukan resampling kembali.

Dalam penelitian ini metode resampling yang digunakan adalah jackknifing. Metode resampling jackknifing memiliki kelebihan yaitu jackknifing memiliki parameter yang lebih stabil dalam estimasi dengan analisis yang menyesatkan.Köck dan Paramythis (2011) metode Jackknifing juga dianggap merupakan alat analisis yang lebih baik daripada bootstrapping untuk mengatasi masalah yang terkait dengan kehadiran outlier karena kesalahan dalam pengumpulan data.

\section{Pengembangan Path Diagram}

Atas dasar model teoritik maka sebuah diagram Path dapat dikembangkan pada gambar 3.1 sebagai berikut:

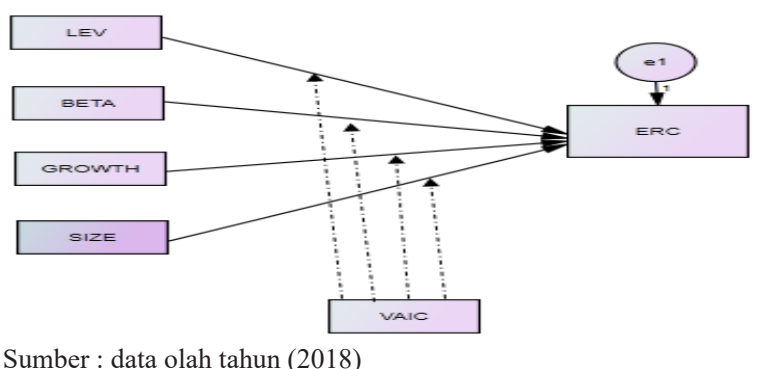

Sumber : data olah tahun (2018)

\section{Gambar 1. Path Analysis - Model Specification}

Konstruk-konstruk yang dibangun dalam gambar 1 dapat dibedakan dalam dua kelompok kontruk yaitu konstruk exogen dan kontruk endogen yang diuraikan berikut ini:

1. Konstruk Exogen (Exogenous Construct). Konstruk exogen dikenal sebagai source variable atau independent variable yang tidak diprediksi oleh variable lain dalam model. Dalam gambar di atas terdapat 2 (dua) konstruk eksogen yaitu; Net Working Capital dan Capital Expenditure.

2. Konstruk Endogen (Endogen Construct). Konstruk Endogen adalah faktor-faktor yang diprediksi oleh satu atau beberapa konstruk. Konstruk Endogen dapat diprediksi satu atau beberapa konstruk endogen lainnya, tetapi konstruk eksogen hanya dapat berhubungan kausal dengan konstruk endogen. Gambar 3.1. Konstruk endogen dalam kode tersebut adalah, Cash Holding. Adapun konversi diagram alur ke dalam persamaan, berikut: 


\section{Konversi Diagram Alur Kedalam Persamaan}

Persamaan jalur yang dibangun sebagai berikut:

$\mathrm{Y} 1: \beta 0+\beta 1 \mathrm{X} 1+\beta 2 \mathrm{X} 2+\beta 3 \mathrm{X} 3+\beta 4 \mathrm{X} 4+\beta 5 \mathrm{X} 1 *$ $\mathrm{M} 1+\beta 6 \mathrm{X} 2 * \mathrm{M} 1+\beta 7 \mathrm{X} 3 * \mathrm{M} 1+\beta 8 \mathrm{X} 4 * \mathrm{M} 1+\mathrm{e}$

Dimana:

$\mathrm{X} 1$ : Leverage

$\mathrm{X} 2$ : Resiko Sistematis

$\mathrm{X} 3$ : Growth Opportunities

$\mathrm{X} 4$ : Firm Size

$\mathrm{Y}: \mathrm{ERC}$

M1 : Value Added Intelectual

E : Eror

\section{HASIL}

Pengambilan sampel dalam penelitian ini menggunakan metode purposive sampling, yaitu teknik sampling dengan menggunakan pertimbangan dan batasan tertentu sehingga sampel yang dipilih relevan dengan tujuan penelitian, dimana peneliti menetapkan kriteria pemilihan sampel yang akan diteliti adalah perusahaan-perusahaan tersebut telah melakukan chas holding. Adapun perhitungan sampel diperoleh 58 perusahaan jasa keuangan.

Tabel 1. Perhitungan Sampel Diperoleh 58 Perusahaan Jasa Keuangan

\begin{tabular}{rlcc}
\hline No & Langkah Pengambilan Sampel & \multicolumn{1}{c}{$\begin{array}{c}\text { Total } \\
\text { Perusahaan }\end{array}$} \\
\hline 1 & $\begin{array}{l}\text { Total Perusahaan otomotif dan } \\
\text { komponen yang listing di BEI } \\
\text { berdasarkan ICMD tahun 2013-2017 }\end{array}$ & 60 \\
2 & $\begin{array}{l}\text { Tidak menerbitkan laporan } \\
\text { keuangan pada tahun tertentu } \\
\text { dalam tahun penelitian }\end{array}$ \\
3 & $\begin{array}{l}\text { Data untuk variable penelitian tidak } \\
\text { lengkap }\end{array}$ \\
4 & Total sampel & \\
\hline
\end{tabular}

Sumber: Indonesian Capital Market Directory, yang diolah kembali (2018)

Tabel 2. Statistik Deskriptif

\begin{tabular}{cccc}
\hline & ERC & LEV (X1) & BETA (X2) \\
\hline Min & -7.333 & -1.863 & -6.549 \\
Max & 0.540 & 2.057 & 1.808 \\
Median & 0.164 & -0.056 & 0.129 \\
Mode & 0.164 & -1.863 & -6.549 \\
Mean & 502015642,46 & 2714660870,58 & 870391673,51 \\
SD & 215438 & 588752769,702 & 462236818,91 \\
& 649,700 & & \\
\hline
\end{tabular}

\begin{tabular}{cccc}
\hline & $\begin{array}{c}\text { GROWTH } \\
\text { (X3) }\end{array}$ & SIZE(X4) & VAIC (M) \\
\hline Min & -0.937 & -1.586 & -6.668 \\
Max & 4.596 & 2.530 & 0.987 \\
Median & -0.338 & -0.232 & 0.200 \\
Mode & -0.912 & -1.586 & -6.668 \\
Mean & 171,3833 & 103296522,36 & $-222980923,75$ \\
SD & 159,39133 & 1815628403,51 & 1060405485,68 \\
\hline
\end{tabular}

Sumber : Indonesian Capital Market Directory, yang diolah kembali (2018)

Notasi :

$\begin{array}{ll}\text { ERC } & \text { : Earnings Response Coefficient } \\ \text { LEV } & : \text { Leverage } \\ \text { BETA } & \text { : Resiko Sistematis } \\ \text { GROWTH } & \text { : Growth Opportunities } \\ \text { SIZE } & \text { : Ukuran Perusahaan } \\ \text { VAIC } & \text { : Value Added Intelectual Capital }\end{array}$

Statistik Deskriptif tentang variabel penelitian menggambarkan bahwa variabel Earnings Response Coefficient (ERC) memiliki nilai minimum sebesar $-7,333$, nilai maksimum sebesar 0,540 ; dengan ratarata 502015642,46 dengan standar deviasi sebesar 215438649,70049. Mean ERC lebih besar dari Standar Deviasi nya; hal ini menunjukkan bahwa data variabel ERC kondisinya baik. Variabel Leverage memiliki nilai minimum sebesar -1.863 , nilai maksimum sebesar 2.057, dengan rata-rata sebesar 2714660870,58; dengan standar devisi sebesar 588752769,70245. Standar deviasi Leverage lebih besar dari rata-ratanya; hal ini menunjukkan bahwa data variabel Leverage berfluktuasi. Variabel Resiko Sistematis (BETA) memiliki nilai minimum sebesar -6.549 , nilai maksimum sebesar 1.808, dengan rata-rata sebesar 870391673,5167; dengan standar deviasi sebesar 462236818,91.

Mean Risiko Sistematis lebih besar dari Standar Deviasi nya; hal ini menunjukkan bahwa data variabel Risiko Sistematis kondisinya baik. Variabel Growth Opportunities memiliki nilai minimum sebesar -0.937 , nilai maksimum sebesar 4.596, dengan rata-rata sebesar 171,3833; dengan standar deviasi sebesar 159,39133. Mean Growth Opportunities lebih besar dari Standar Deviasi nya; hal ini menunjukkan bahwa data variabel Growth Opportunities kondisinya baik. Variabel VAIC memiliki nilai minimum sebesar -6.668 , nilai maksimum sebesar 0.987 ; dengan rat-rata sebesar -222980923,7500 Standar deviasi VAIC lebih besar dari rata-ratanya; hal ini menunjukkan bahwa data variabel VAIC berfluktuasi. 
Tabel 3. Hasil Moderating Coefficient dan P-Value Perusahaan Jasa Keuangan

\begin{tabular}{|c|c|c|c|c|c|}
\hline \multirow{2}{*}{ No } & Hubungan & \multirow{2}{*}{\multicolumn{2}{|c|}{ KoefisienP-Value }} & \multirow[b]{2}{*}{ SE. } & \multirow[b]{2}{*}{ Keterangan } \\
\hline & $\begin{array}{c}\text { Antar } \\
\text { Variabel }\end{array}$ & & & & \\
\hline 1 & $\mathrm{LEV} \rightarrow \mathrm{ERC}$ & 0,18 & 0,09 & 0.123 & $\begin{array}{c}\text { Tidak } \\
\text { signifikan }\end{array}$ \\
\hline 2 & $\mathrm{BETA} \rightarrow \mathrm{ERC}$ & $-0,23$ & $0.05 * * *$ & 0.121 & $\begin{array}{c}\text { Signifikan } \\
10 \%\end{array}$ \\
\hline 3 & $\begin{array}{l}\text { GR OWTH } \rightarrow \\
\text { ERC }\end{array}$ & -0.18 & $0.10 * * *$ & 0.120 & $\begin{array}{c}\text { Signifikan } \\
10 \%\end{array}$ \\
\hline 4 & SIZE $\rightarrow$ ERC & -0.04 & 0.39 & 0.126 & $\begin{array}{c}\text { Tidak } \\
\text { signifikan }\end{array}$ \\
\hline 5 & $\begin{array}{l}\mathrm{LEV}^{*} \mathrm{VAIC} \rightarrow \\
\mathrm{ERC}\end{array}$ & -0.04 & 0.38 & 0.129 & $\begin{array}{c}\text { Tidak } \\
\text { signifikan }\end{array}$ \\
\hline 6 & $\begin{array}{l}\text { BETA } *^{*} \\
\text { VAIC } \rightarrow \text { ERC }\end{array}$ & 0.02 & 0.45 & 0.124 & $\begin{array}{c}\text { Tidak } \\
\text { signifikan }\end{array}$ \\
\hline 7 & $\begin{array}{l}\text { GROWTH* } \\
\text { VAIC } \rightarrow \text { ERC }\end{array}$ & -0.10 & 0.23 & 0.124 & $\begin{array}{c}\text { Tidak } \\
\text { signifikan }\end{array}$ \\
\hline 8 & $\begin{array}{l}\mathrm{SIZE}^{*} \mathrm{VAIC} \rightarrow \\
\mathrm{ERC}\end{array}$ & 0.06 & 0.34 & 0.125 & $\begin{array}{c}\text { Tidak } \\
\text { signifikan }\end{array}$ \\
\hline
\end{tabular}

Sumber : data diolah digunakan dalam penelitian ini (2018)

Notasi :

ERC : Earnings Response Coefficient, LEV : Leverage, BETA : Risiko Sistematis, GROWTH : Growth Opportunities, SIZE: Ukuran Perusahaan, VAIC :Value Added Intelectual Capital.

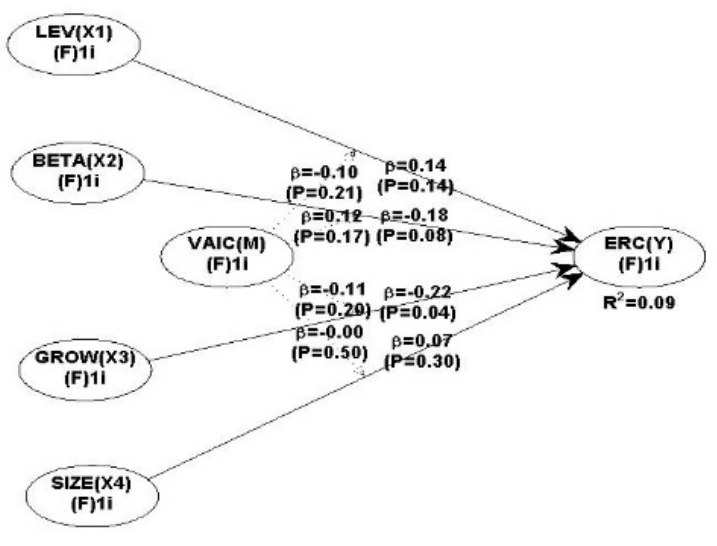

Gambar 2. Model Single Moderator hubungan LEV, Beta, Growth dan Size terhadap ERC

\section{PEMBAHASAN}

\section{Pengaruh Leverage Terhadap Earnings Response Coefficient (ERC)}

Dari hasil olah data untuk pengujian hipotesis H1 menunjukkan bahwa pada persamaan model variabel Leverage tidak berpengaruh secara negativ terhadap ERC, dengan coefisien sebesar 0,18 dan p-value sebesar 0,09 (lebih besar dari 0,05). Hasil ini menunjukkan bahwa selama periode penelitian, Leverage perusahaan telah jatuh tempo, mengakibatkan menjadi beban pembayaran hutang jangka panjang perusahaan; meningkatnya beban perusahaan akan mengurangi laba perusahaan, sehingga tidak berdampak kepada kualitas laba atau Earning Response Coefficient (ERC).

Hasil penelitian ini sejalan dengan penelitian yang dilakukan oleh Maisil Delvira dan Nelvirita, 2013, Medy Nisrina M., Vinola Herawaty (2016)dan Hapsari, Hanung Desy dan Panabut Simorangkir. (2013), bahwa leverage tidak berpengaruh terhadap ERC. Dan bertentangan penelitian yang dilakukan oleh Trirriadi, (2012) yang membuktikan bahwa leverage berpegaruh terhadap ERC.

\section{Pengaruh Risiko Sistematis Terhadap Earnings Response Coefficient (ERC)}

Dari hasil olah data untuk pengujian hipotesis H2 menunjukkan bahwa pada persamaan model variabel Beta berpengaruh secara signifikan terhadap ERC, dengan coefisien sebesar $-0,23$ dan p-value sebesar 0.05 (lebih kecil dari $0,10)$. Hasil ini membuktikan bahwa semakin besar risiko akan menurunkan respon laba (ERC), dan sebaliknya semakin kecil risiko akan meningkatkan Respon laba (ERC). Hasil penelitian ini sejalan dengan penelitian yang dilakukan oleh Rahmat Arif, 2016, bahwa Beta berpengaruh terhadap ERC. Bertentangan penelitian yang dilakukan oleh Maisil Delvira dan Nelvirita, 2013 yang membuktikan bahwa Beta tidak berpegaruh terhadap ERC. Meskipun operasional perusahaan berjalan dengan baik dan harga saham tidak ada alasan untuk turun, namun tetap saja pasar bereaksi negatif akibat munculnya resiko pasar. Semakin berfluktuasi perubahan saham akibat kondisi pasar (menyebabkan beta tinggi), pendapatan yang akan diterima investor pada akhir periode akan sulit diprediksi.

\section{Pengaruh Growth Terhadap Earnings Response Coefficient (ERC)}

Dari hasil olah data untuk pengujian hipotesis H3 menunjukkan bahwa pada persamaan model variabel Growth berpengaruh secara signifikan terhadap Earnings Response Coefficient (ERC), dengan coefisien sebesar -0.18 dan p-value sebesar 0.10 (lebih kecil dari 0.10). Hasil penelitian ini mennjukkan bahwa perusahaan otomotif dan komponen mengalami pertumbuhan laba yang baik, semakin meningkatnya Growth Opportunity 
akan meningkatkan respon laba (ERC) dan sebaliknya semakin menurunnya Growth akan menurunkan respon laba (ERC). Hasil penelitian ini sejalan dengan penelitian yang dilakukan oleh Rahmat Arif, 2016, bahwa Growth berpengaruh terhadap Earnings Response Coefficient (ERC). Bertentangan dengan penelitian yang dilakukan Novi Liya Sari ,Rulfah M. Daud 2016) yang menemukan bahwa Growth tidak berpengaruh terhadap Earnings Response Coefficient (ERC). Berdasarkan hasil analisis statistik dalam penelitian ini ditemukan bahwa hipotesis ketiga (H3) ditolak. Koefisien regresi dari ukuran perusahaan adalah 0,308 dengan $t$ sebesar 1,732 dan signifikansi $0,105>0,05$. Dengan demikian, penelitian ini membuktikan bahwa ukuran perusahaan tidak berpengaruh terhadap kualitas laba

\section{Pengaruh Size Terhadap Earnings Response Coefficient (ERC)}

Dari hasil olah data untuk pengujian hipotesis H4 menunjukkan bahwa pada persamaan model variabel Size tidak berpengaruh secara terhadap Earnings Response Coefficient (ERC), dengan coefisien sebesar -0.04 dan p-value sebesar 0.39 (lebih besar dari 0,05). Hasil penelitian ini menunjukkan bahwa perusahaan Otomotif dan Komponen memiliki aset perusahaan yang tidak di manfaatkan untuk memperoleh profitabilitas. Sehingga aset yang dimiliki belum mampu mendorong terciptanya keuntungan perusahaan, sehingga ukuran perusahaan (size) tidak berpengaruh terhadap ERC. Hasil penelitian ini sejalan dengan penelitian yang dilakukan oleh Hapsari, Hanung Desy dan Panabut Simorangkir. (2013), bahwa Size tidak berpengaruh terhadap Earnings Response Coefficient (ERC). Dan bertentangan penelitian yang dilakukan oleh Rahmat Arif, 2016 yang menemukan bahwa Size berpengaruh terhadap Earnings Response Coefficient (ERC).

\section{Pengaruh Leverage, Beta, Growth, dan Firm Size Terhadap Earnings Response Coefficient (ERC), Dengan VAIC sebagai Pemoderasi}

Dari hasil olah data untuk pengujian hipotesis H1.a menunjukkan bahwa pada persamaan model variabel VAIC tidak memoderasi hubungan antara Leverage terhadap $E R C$, dengan coefisien sebesar $-0,04$ dan p-value sebesar 0,38 (lebih besar dari $0,05)$. Dengan demikian $V A I C$ tidak memoderasi hubungan antara Leverage terhadap $E R C$.

Dari hasil olah data untuk pengujian hipotesis
H2.a menunjukkan bahwa pada persamaan model variabel VAIC tidak memoderasi hubungan antara Beta terhadap ERC, dengan coefisien sebesar 0,02 dan p-value sebesar 0,45 (lebih besar dari $0,05)$. Dengan demikian VAIC tidak memoderasi hubungan antara Beta terhadap ERC.

Dari hasil olah data untuk pengujian hipotesis H3.a menunjukan bahwa pada persamaan model variabel VAIC tidak memoderasi hubungan antara Growth terhadap $E R C$, dengan coefisien sebesar $-0,10$ dan p-value sebesar 0,23 (lebih besar dari $0,05)$. Dengan demikian $V A I C$ tidak memoderasi hubungan antara Growth terhadap ERC. Hasil penelitian ini membuktikan bahwa VAIC, tidak dapat memperkuat hubungan antara variabel Leverage, Beta, growth dan size terhadap ERC. Dengan demikian variavel VAIC tidak digunakan sebagai variabel pemoderasi.

\section{SIMPULAN}

Berdasarkan hasil pembahasan, dapat disimpulkan beberapa temuan yang terkait dengan penelitian, antara lain: Leverage tidak berpengaruh terhadap ERC, artinya semakin besar Leverage tidak memberikan pengaruh respon terhadap peningkatan kualitas laba.

Risiko sistematis berpengaruh negatif terhadap $E R C$, artinya semakin besar resiko sistematis memberikan pengaruh penurunan $E R C$, dimana tingginya risiko sistematis akan menurunkan tingkat laba perusahaan dan berakibat turunnya $E R C$.

Growth Opportunities berpengaruh positif terhadap ERC, artinya semakin besar Growth Opportunities memberikan pengaruh peningkatan ERC. Sebaliknya semakin kecil Growth Opportunities akan memberikan pengaruh menurunnya $E R C$.

Firm Size tidak berpengaruh terhadap ERC, artinya perusahaan tidak mampu memanfaatkan aset yang dimiliki untuk menciptakan profitabilitas perusahaan, perusahaan hanya bertumpu pada aktifitas sales, sehingga pemanfaatn aset tidak memberikan kontribusi terhadap respon laba (ERC).

Pengaruh Leverage, Beta, growth dan size terhadap $E R C$. Dengan $V A I C$ sebagai Pemoderasi. Hasil penelitian ini membuktikan bahwa VAIC, tidak dapat memperkuat hubungan antara variabel Leverage, Beta, growth dan size terhadap ERC. Dengan demikian variavel VAIC tidak digunakan sebagai variabel pemoderasi. 


\section{DAFTAR PUSTAKA}

Abdullah. (2016). Free Cash Flow, Agency Theory Dan Signaling Theory: Konsep dan Riset Empiris. Jurnal Akuntansi dan Investasi, 3(2), 151-170.

Abdurrasyid, P. (2011). Arbitrase dan Alternatif Penyelesaian Sengketa, Cetakan Kedua. Jakarta: PT. Fikahati Aneska.

Adhani, Y., \& Subroto, B. (2014). Relevansi Nilai Informasi Akuntansi . Jurnal Ilmiah Mahasiswa Fakultas Ekonomi dan Bisnis Universitas Brawijaya, Vol. 2 No. 2.

Agustiningrum, S. A. (2020). Pengaruh Intellectual Capital, Leverage dan Profitability terhadap Earning Response Coefficient dengan Corporate Social Responsibility Disclosure sebagai Moderating Variable pada Perusahaan Indeks LQ-45 Terdaftar di BEI Tahun 20152019 (Doctoral dissertation, STIE Perbanas Surabaya).

Arifin, H. N. (2015). Pengujian Efisiensi Pasar Modal Bentuk Setengah KuatSecara Informasi Terhadap PeristiwaMerger Dan Akuisisi. Jurnal Universitas Negeri Yogyakarta.

Brigham, E. F., \& Houston, J. F. (2011). Dasardasar Manajemen Keuangan. Diterjemahkan oleh: Ali Akbar Yulianto, Buku 2, Edisi 11. Jakarta: Salemba Empat.

Delvira, M., \& Nelvirita, N. (2013). Pengaruh Risiko Sistematik, Leverage Dan Persistensi Laba Terhadap Earnings Response Coefficient (ERC). Wahana Riset Akuntansi, 1(1).

Dewi, S. (2011). Faktor yang Mempengaruhi Koefisien Respon Laba. Jurnal Ilmiah Berkala 6 Bulanan. Vol 16 No 1. Hlm 17-21.

Gamayuni, R. R. (2011). Analisis Ketepatan Model Altman sebagai Alat untuk Memprediksi Kebangkrutan (Studi Empiris pada Perusahaan Manufaktur di BEI). Jurnal Akuntansi dan Keuangan, 16(2), 158-176.

Ghosh, SK, \& Maji, SG (2015). Validitas empiris model koefisien intelektual nilai tambah di sektor berbasis pengetahuan India. Ulasan Bisnis Global , 16 (6), 947-962.

Ghozali, Imam., \& Hengky Latan. 2014. Partial Least Squares : Konsep, Teknik dan Aplikasi Menggunakan Program SmartPLS3.0 edisi kedua. Universitas Diponegoro, Semarang.

Halim, A. (2015). Manajemen Keuangan Bisnis: Konsep dan Aplikasinya. Edisi pertama. Jakarta: Mitra Wacana Media.
Hanafi, M. M. (2016). Manajemen Keuangan (Edisi 2). Cetakan Pertama. Yogyakarta: BBPE.

Hapsari, H. D., \& Simorangkir, P. (2013). Faktor-faktor yang Mempengaruhi Earnings Response Coeffiecient (ERC) Pada Perusahaan Kompas 100 yang Terdaftar di Bursa Efek Indonesia Periode 2009-2010. Jurnal Akuntansi \& Bisnis, Vol. 1, No.1: 118-146.

Herdirinandasari, S. S. \& Nur Fadjrih Asyik. (2016). Pengaruh Ukuran Perushaan, Profitabilitas dan Valuntary Disclousure Terhadap Earning Respon Coefficient, Jurnal Ilmu dan Riset Akuntansi : Volume 5, Nomor 11, November (2016).

Husiano, D. (2016), Analisis Pengaruh Beta, Leverage, Dividend Payout Ratio, dan Earnings Persistence terhadap Earnings Response Coefficient pada Indeks Kompas 100 Jurnal Riset Akuntansi dan Perpajakan, JRAP Vol. 1 no. 2, hal 121-135.

Imroatussolihah, E. (2013). Pengaruh Risiko, Leverge, Peluang Bertumbuh, Persistensi Laba dan CSR Terhadap Earnings Response Coeffiecient (ERC) PADA PERUSAHAAN HIGH PROFILE. Jurnal Ilmiah Manajemen | Volume 1 Nomor 1 Januari 2013.

Ikatan Akuntansi Indonesia, (2012). Standar Akuntansi Keuangan. PSAK. Cetakan Keempat, Buku Satu, Jakarta: Penerbit Salemba Empat.

Jati, N. A., Khairunnisa, K., \& Yudowati, S. P. (2017). Pengaruh Risiko Sistematik, Persistensi Laba, Dan Ukuran Perusahaan Terhadap Koefisien Respon Laba (studi Pada Perusahaan Yang Terdaftar Di Indeks Kompas100 Periode 2011-2015). eProceedings of Management, 4(3).

Jogiyanto. (2013). Teori Portopolio dan Analisis Investasi, Yogyakarta: BPFE.

Kasmir. (2015). Analisis Laporan Keuangan. Jakarta: PT Raja Grafindo Persada.

Kurnia, I., \& Sufiyati. (2015). Pengaruh Ukuran Perusahaan, Leverage, Risiko Sistematik, Dan Investment Opportunity Set Terhadap Earnings Response Coefficient Pada Perusahaan Manufaktur Yang Terdaftar Di Bursa Efek Indonesia Pada Tahun 2012-2014. Jurnal Ekonomi, 20(3), 463-478.

Kuswanto, R., Rambe, P. A., \& Ruwanti, S. (2016). Relevansi Nilai Informasi Akuntansi Pada Perusahaan Manufaktur yang Terdaftar di Bursa Efek Indonesia pada tahun (2013-2014). Jurnal Fakultas Ekonomi Universitas Maritim Raja Ali Haji. Kepulauan Riau. 
Mawarni, R. (2014). Pengaruh Kesempatan Investasi, Leverage, dan Likuiditas pada Kebijakan Dividen Perusahaan Manufaktur yang terdaftar di BEI, E-Jurnal Akuntansi, 9(1), 200-208.

Naimah, Z. (2014). Relevansi Nilai Informasi Akuntansi: Suatu Kajian Teoritis. Jurnal Buletin Studi Ekonomi, Vol. 19. No. 1, Februari (2014).

Nisrina M., \& Herawaty, V. (2016). Growth Opportunity, Earnings Response Coefficient, Persistence, Leverage, Earnings Response Coefficient, Intellectual Capital, Jurnal TEKUN, Univwrsitas Trisakti Vol.VI., No.1 Maret (2016).

Nuraina, E. (2012). Pengaruh Kepemilikan Institusional dan Ukuran Perusahaan terhadap Kebijakan Hutang dan Nilai Perusahaan. Jurnal Bisnis dan Ekonomi Vol. 19, No. 2, September (2012), Hal. 110-12.

Nuswandari, C. (2013). Determinan Struktur Modal dalam Perspektif Pecking Order Theory dan Agency Theory. Dinamika Akuntansi, Keuangan dan Perbankan, Mei (2013), Hal. 92102.

Paramita, R. W. D. (2012). Pengaruh leverage, firm size dan voluntary disclousure terhadap earnings response coeffisient (erc). WIGA-Jurnal Penelitian Ilmu Ekonomi, 2(2).

Pradipta, D. H., \& Purwaningsih, A. (2013). Pengaruh Luas Pengungkapan Tanggung Jawab Sosial dan Lingkungan Perusahaan terhadap Earning Response Coefficient (ERC), dengan Ukuran Perusahaan dan Leverage Sebagai Variabel Kontrol. Universitas Atma Jaya..

Punamasari, \& Wida. N. L. P. (2014). Relevansi Nilai: Informasi Nilai Laba, Arus Kas, Nilai, Buku, Goodwill, dan Ukuran Perusahaan yang Membentuk Keputusan Ekonomi Investor. Jurnal Mahasiswa Fakultas Ekonomi Universitas Negeri Surabaya.

Ratmono, I, (2015). Determinan Kebijakan Dividen Perusahaan: Pengujian Terhadap Teori Siklus Hidup. Jurnal Dinamika Akuntansi, 7.

Sandi, K. U. (2013). Faktor-Faktor yang Mempengaruhi Earnings Response Coefficient. Accounting Analysis Journal, 2(3).

Sari, N. L., \& Daud, R. M. (2016). Pengaruh Informasi Laba Terhadap Koefisien Respon Laba (Studi Empiris Pada Perusahaan Manufaktur Yang Terdaftar Di Bei Pada Tahun (2011-2014), Jurnal Ilmiah Mahasiswa Ekonomi Akuntansi (JIMEKA) Vol. 1, No. 2, (2016) Halaman 227-236.

Sartono, A. (2012). Manajemen Keuangan:
Teori Praktik. Edisi Kempat. Cetakan keenam. Yogyakarta: BPPE.

Silaban, P. (2016). Pengaruh Profitabilitas, Struktur Kepemilikan, Pertumbuhan Perusahaan Dan Efektivitas Usaha Terhadap Kebijakan Dividen Pada Perusahaan Manufaktur. E-Jurnal Manajemen Universitas Udayana, 5(2).

Silalahi, S. P. (2014). Pengaruh Corporate Social Responsibility (CSR) Disclousure, Beta dan Price to Bokk Value (PBV) Terhdap Earning Response Coefficient (ERC), Jurnal Ekonomi, Volume 22, Nomor 1 Maret 2014.

Subramanyan, K. R, \& John J. Wild. (2012). Analisis Laporan Keuangan. Edisi 10. (Penerjemah: Dewi Yanti). Jakarta: Salemba Empat.

Sudirman, I. FAKTOR-FAKTOR YANG MEMPENGARUHI EARNINGS RESPONSE COEFFICIENT (ERC) PADA PERUSAHAAN YANG TERDAFTAR DI BURSA EFEK INDONESIA (Periode 2011-2015).

Sulistyorini, Y. (2016). Pengaruh Sales Growth (SG) dan Return On Asset (ROA) terhadap Debt to Equity Ratio (DER) dimoderasi oleh firm size (pada perusahaan sektor pertanian yang listing di BEI periode 2011-2014). Pengaruh Sales Growth (SG) dan Return On Asset (ROA) terhadap Debt to Equity Ratio (DER) dimoderasi oleh firm size (pada perusahaan sektor pertanian yang listing di BEI periode 2011-2014)/Yohana Sulistyorini.

Sutrisno. (2012). Manajemen Keuangan Teori. Konsep dan aplikasi (8th ed). Yogyakarta: Ekonisia.

Syakur, A. S.. (2015). Intermediate Accounting. Jakarta : AV Publisher.

Tritiadi, B., \& Yuyeta, N. E. A. (2012). Analisis Perbedaan Pengaruh Informasi Laba dan Rugi Terhadap Koefisien Respon Laba. Diponegoro Journal Of Accounting. Vol 1 N0 2. Hlm 1-13.

Utami, M. S. (2015). Pengaruh Beta, Konservatisme Akuntansi, Corporate Social Responsibility Terhadap Koefisien Respon Laba Pada Perusahaan Manufaktur Yang Terdaftar Dibursa Efek Indonesia (BEI) Tahun 2010-2013, Jurnal Akuntansi Universitas Maritim Raja Ali Haji (UMRAH) Tanjungpinang.

Ulum, I., Kharismawati, N., \& Syam, D. (2017). Koefisien intelektual nilai tambah yang dimodifikasi (MVAIC) dan kinerja keuangan tradisional perusahaan terbesar di Indonesia. Jurnal Internasional Pembelajaran dan Modal Intelektual , 14 (3), 207-219. 